\title{
CONTROLE DA CALOGÊNESE DO PAU-BRASIL in vitro ${ }^{1}$
}

\author{
Elias Terra Werner ${ }^{2}$, Geraldo Rogério Faustini Cuzzuol ${ }^{3}$, Kamila Vilas Pessotti²,Fernando Pinto Lopes ${ }^{4}$ \\ e Jéssica de Almeida Roger ${ }^{4}$
}

\begin{abstract}
RESUMO - A indução da calogênese é a primeira etapa para obtenção de embriões e sementes. Para o controle da calogênese de Caesalpinia echinata, foram usados discos de foliólolos do pau-brasil em diferentes fases de desenvolvimento combinados com os fitorreguladores 2,4-D $(0,5,10,20,50,100 \mathrm{mg} / \mathrm{L})$ e 6-BAP $(2,0 \mathrm{mg} /$ L), cultivados em meio de cultura de Murashige e Skoog (1962) acrescido de sacarose (30 g/L), mioinositol $(100 \mathrm{mg} / \mathrm{L})$ e ágar (7,5 g/L). Foi testado, também, o efeito de 6-BAP $(0,0,5,1,0,2,0,5,0$ e $10 \mathrm{mg} / \mathrm{L})$ no crescimento de ápices meristemáticos. Foliólolos juvenis cultivados com baixa concentração de 2,4-D (5 e $20 \mathrm{mg} / \mathrm{L}$ ) e foliólolos jovens tratados com altas concentrações de 2,4-D (50 e $100 \mathrm{mg} / \mathrm{L})$ geraram calos sem diferenças significativas entre luz e escuro. Quanto ao controle da oxidação, melhores resultados foram proporcionados pelo carvão ativado, porém inibidores da calogênese. A transferência dos calos do meio de cultura MS com altas concentrações de 2,4-D $(5,0 ; 10,0 ;$ e 20,0 mg/L) para meio sem fitorreguladores estimulou a formação de massas pró-embrionárias (MPEs). Os meios livres de fitorreguladores, 2,0 mg/L de 2,4-D e 0,5 mg/L de 2,4-D elevaram o número de calos embriogênicos e de massas pré-embrionárias. Somente em 0,5 mg/L 2,4-D se verificaram algumas estruturas semelhantes a embriões somáticos nas fases globular e codiforme.
\end{abstract}

Palavras-chave: Caesalpinia echinata, calos e oxidação.

\section{In vitro CALOGENESIS CONTROL OF PAU-BRASIL}

\begin{abstract}
The present work dealt with the in vitro control of callogenesis of brazilwood. The induction of callogenesis is the first step to obtain embryos and seeds. In order to control the callogenesis of Caesalpinia echinata, leaf discs of brazilwood in different developmental stages were used combined with the growth regulators 2,4-D $(0,5,10,20,50,100 \mathrm{mg} / \mathrm{L})$ and 6-BAP $(2,0 \mathrm{mg} / \mathrm{L})$, cultivated in the Murashige and Skoog (1962) medium supplemented with sucrose $(30 \mathrm{~g} / \mathrm{L})$, myo-inositol $(100 \mathrm{mg} / \mathrm{L})$ and agar $(7,5 \mathrm{~g} / \mathrm{L})$. The effect of 6 $\operatorname{BAP}(0,0,5,1,0,2,0,5,0$ and $10 \mathrm{mg} / \mathrm{L})$ on the growth of meristematic shoot apexes was also tested. Juvenile leaves cultured with low concentrations of 2,4-D $(5$ and $20 \mathrm{mg} / \mathrm{L})$ and young leaves treated with high concentrations of 2,4-D (50 and $100 \mathrm{mg} / \mathrm{L})$ produced callus, without presenting significant differences between light and dark. As for the oxidation control, the best results were provided by activated charcoal, which inhibited callogenesis. The transfer of callus from the MS culture medium with high concentrations of 2,4-D (5,0,10,0 and 20,0 $\mathrm{mg} / \mathrm{L})$ to the medium without growth regulators stimulated the formation of pro-embryonic masses (PEMs). The media without growth regulators, 2,0 $\mathrm{mg} / \mathrm{L}$ of 2,4-D and 0,5 $\mathrm{mg} / \mathrm{L}$ of 2,4-D, increased the number of embryogenic calluses and pre-embryonic masses. There were structures similar to global and heart shaped somatic embryos only at $0,5 \mathrm{mg} / \mathrm{L} \mathrm{2,4-D}$.
\end{abstract}

Keywords: Caesalpinia echinata, callus and oxidation.

\section{INTRODUÇÃO}

Caesalpinia echinata Lam (Fabaceae), conhecida popularmente como pau-brasil, é planta semidecídua e semi-heliófila da Floresta Estacional Caducifólia Costeira
(CARVALHO, 1994; AGUIAR et al., 2005) distribuída na costa brasileira entre o Rio de Janeiro e o Rio Grande do Norte (LIMA, 1992). Sua exploração predatória na época da colonização, aliada às características recalcitrantes de suas sementes (BARBEDO et al., 2002),

\footnotetext{
${ }^{1}$ Recebido em 09.05.2008 e aceito para publicação em 23.06.2009.

${ }^{2}$ Programa de Pós-Graduação em Biologia Vegetal, Universidade Federal do Espírito Santo, Departamento de Botânica, Vitória, ES.E.mail: <elias_werner@ig.com.br>e<k_pessotti@hotmail.com>.

${ }^{3}$ Universidade Federal do Espírito Santo, Setor de Botânica, Dep. de Ciências Biológicas/CCHN, Vitória, ES. E-mail:<gcuzzuol@gmail.com>. ${ }^{4}$ Bacharel em Ciências Biológicas. Universidade Federal do Espírito Santo, UFES, Brasil. E-mail:<fefe_ufes@yahoo.com.br> e <jessiebio@yahoo.com.br>.
} 
contribuiu para que $C$. echinata fosse incluída na lista de espécies ameaçadas ou em perigo de extinção (BRASIL, 1992; AGUIAR et al., 2007).

Uma das estratégias eficientes para promover a conservação de espécies ameaçadas consiste na criação de banco de germoplasma in situ e ex situ. Nesse último caso, um método bastante conhecido é a propagação de plantas in vitro através da indução de embriões somáticos ou regeneração de plantas por cultivo de ápices meristemáticos (GUERRA et al., 1999).

Na maioria dos modelos de embriogênese somática, as auxinas são usadas em concentrações relativamente elevadas, e o ácido 2,4-diclorofenoxiacético (2,4-D) é um do mais utilizados nos processos de desdiferenciação celular. É um potente sinalizador no processo de rediferenciação, induzindo a produção de embriões somáticos diretos, sem passar pela fase de calogênese (GUERRA et al., 1999).

A eficiência dos explantes em gerar calos depende da determinação dos tecidos vegetais e de sua especificidade. Algumas espécies são induzidas apenas com 2,4-D, enquanto outras necessitam da combinação de diferentes fitorreguladores, como ácido indolacético (AIA), 6-benzilaminopurina (6-BAP) e ácido naftalenoacético (ANA) (NEWMAN et al., 1996).

Além da definição da composição química para o controle da organogênese in vitro, um desafio encontrado nas técnicas de micropropagação está no controle da oxidação (PREECE e COMPTON, 1991). As substâncias oxidantes mais comumente encontradas em algumas espécies lenhosas cultivadas in vitro são os fenóis, flavonoides e taninos (PAIVA e PAIVA, 2001), bastante representativos em tecidos de arbóreas tropicais (GRATTAPAGLIA e MACHADO, 1998). A idade e a fase de desenvolvimento dos explantes são outros fatores associados à síntese dos compostos fenólicos. De modo geral, explantes mais jovens são menos propícios à oxidação (PAIVA e PAIVA, 2001).

Algumas medidas têm sido recomendadas para evitar a oxidação dos explantes, como a imersão em soluções antioxidantes de ácido cítrico e, ou, ácido ascórbico antes da inoculação (GRATTAPAGLIA e \& MACHADO, 1998), adição de carvão ativado, ácido ascórbico e, ou, polivinilpirrolidone (PVP) ao meio de cultura (PAIVA e PAIVA, 2001).

R. Árvore, Viçosa-MG, v.33, n.6, p.987-996, 2009
O trabalho teve como objetivo desenvolver um protocolo para indução e controle do desenvolvimento de calos visando à embriogênese somática indireta. Estabeleceu, ainda, condições ideais para o controle da oxidação de explantes foliares de C. echinata quando cultivados in vitro.

\section{MATERIAL E MÉTODOS}

\subsection{Material biológico}

Foram utilizados como explantes foliólos de Caesalpinia echinata Lam (Fabaceae) retirados de uma árvore adulta, com aproximadamente 6 anos de idade, do Parque Municipal Pedra da Cebola $\left(20^{\circ} 192\right.$ 0922 S, $40^{\circ} 2025022$ W), em Vitória, ES. Foi selecionado um genótipo com as melhores características morfológicas e fisiológicas, o qual foram retiradas folhas basais e da borda da copa que apresentassem foliólos nas fases juvenil, jovem e adulta de desenvolvimento (Figura 1). As folhas foram acondicionadas em sacolas plásticas, umedecidas e transportadas imediatamente para o Laboratório de Micropropagação de Plantas da Universidade Federal do Espírito Santo, distante $200 \mathrm{~m}$ do local de coleta. Os explantes foram coletados no período de 17/01/2006 a 12/04/2006, quando as árvores se encontravam na fase de crescimento vegetativo.

\subsection{Indução da calogênese}

Testou-se o efeito de seis concentrações de 2,4-D $(0,5,10,20,50$ e $100 \mathrm{mg} / \mathrm{L})$ na indução de calos utilizando foliólolos juvenis, jovens e adultos (Figura1A-C), que depois de inoculados em meio de cultura foram cultivados sob luz ou no escuro constante em esquema fatorial $6 \times 3 \times 2(2,4-D \times$ fase de desenvolvimento $x$ luz/escuro) $\operatorname{com} n=10$. O meio de cultura utilizado foi o MS completo (MURASHIGE e SKOOG, 1962), suplementado com $30 \mathrm{~g} / \mathrm{L}$ de sacarose, 7,5 g/L de ágar e $100 \mathrm{mg} / \mathrm{L}$ de mioinositol. Adicionaram-se as vitaminas tiamina-HCl $(100 \mu \mathrm{g} /$ $\mathrm{L})$, piridoxina- $\mathrm{HCl}(250 \mu \mathrm{g} / \mathrm{L})$ e ácido nicotínico (250 $\mu \mathrm{g} / \mathrm{L})$ e o aminoácido glicina (4 mg/L); $10 \mathrm{~mL}$ do meio de cultura foram vertidos em frascos de vidro (40 $\mathrm{mL}$ ), os quais foram, primeiramente, vedados com papel insufilm PVC e, depois, fechados com papelalumínio. $\mathrm{O}$ pH foi ajustado em 5,8, utilizando-se soluções de $\mathrm{KOH}$ e, ou, $\mathrm{HCl}$ 1,0 M, antes da autoclavagem a $120^{\circ} \mathrm{C}$ e 1 atm por $20 \mathrm{~min}$. 

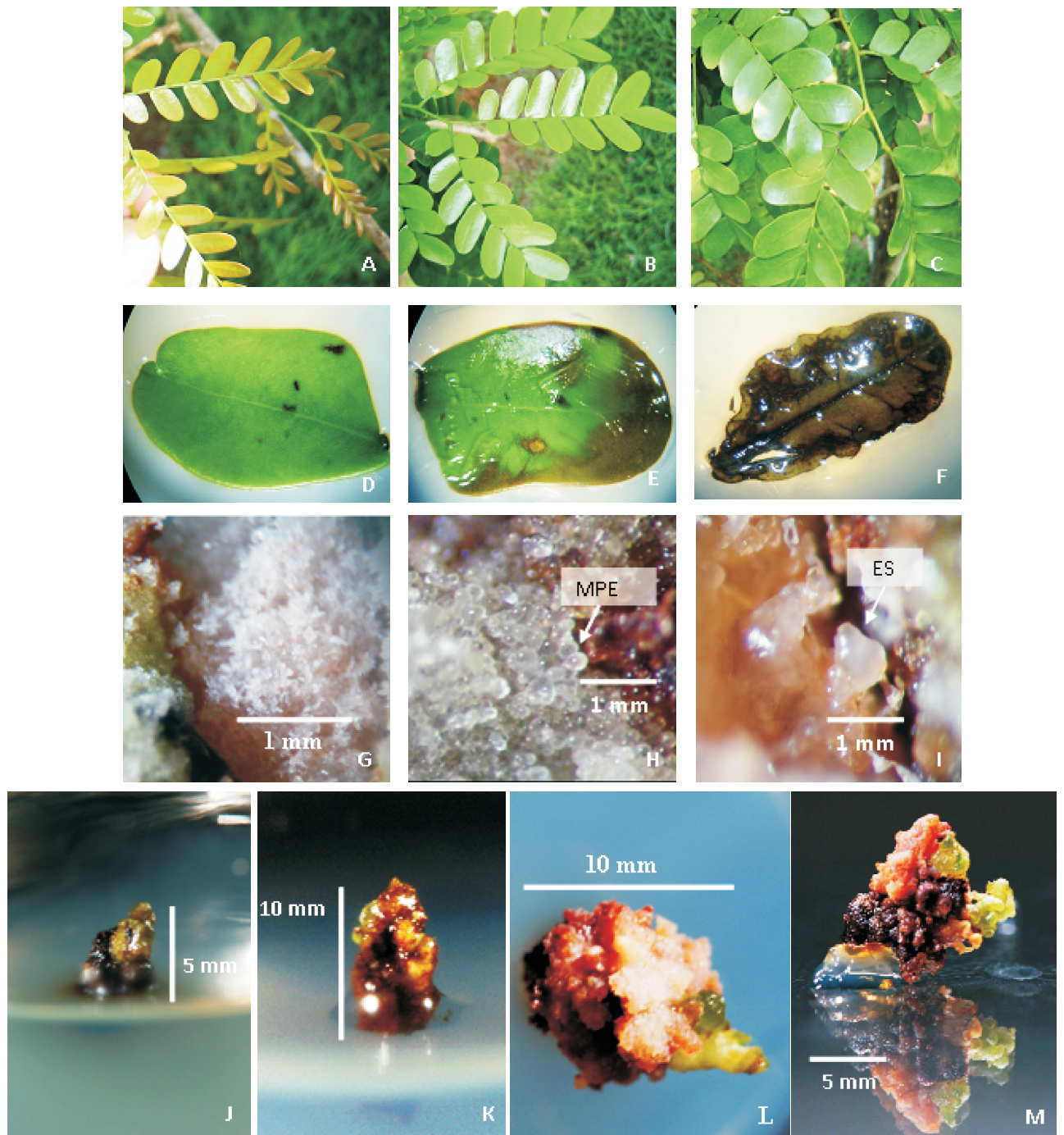

Figura 1 - Aspectos morfológicos dos folíolos juvenis (A), jovens (B) e adultos (C) de C. echinata utilizados como fonte de explantes e níveis de oxidação baixa (D), média (E) e alta (F) dos folíolos cultivados in vitro no meio de cultura MS. Calos apresentando estruturas filamentosas (G), massas pró-embriogênicas - MPE (H) e embrião somático (ES) do tipo torpedo (I). Ápice meristemático aos 7 (J), 20 (K), 30 (L) e 60 dias(M) de cultivo in vitro.

Figure 1 - Morphological aspects of juvenile (A), young (B) and mature leaves $(C)$ of $C$. echinata used as explants and low $(D)$, medium $(E)$ and high oxidation levels $(F)$ of leaves cultured on MS medium. Calluses presenting elongated structures $(G)$, pro-embyogenic masses - MPE $(H)$ and somatic embryo (ES) torpedo shaped (I). Meristimatic shoot apex on the $7^{\text {th }}(\mathrm{J}), 20^{\text {th }}(\mathrm{K}), 30^{\text {th }}(\mathrm{L})$ and $60^{\text {th }}$ day $(M)$ during in vitro culture.

Os folíolos foram lavados com detergente neutro em água corrente durante $10 \mathrm{~min}$, para pré-limpeza e lixiviação de compostos fenólicos. A desinfestação e inoculação dos explantes foram realizadas na câmara de fluxo laminar. Os explantes foram desinfetados em álcool etílico $70 \%$ por 2 min e transferidos para solução de hipoclorito de sódio comercial $40 \%$ (v/v) durante 20 min, sob agitação constante, e enxaguados três vezes com água destilada estéril. Dos folíolos foram retirados discos de $0,7 \mathrm{~cm}$ de diâmetro na região da nervura central, com o auxílio de um perfurador de rolha. O material foi inoculado em meio de cultura e mantido em sala 
de crescimento, na temperatura de $25 \pm 2{ }^{\circ} \mathrm{C}$, sob luz $\left(50 \mu \mathrm{mol} . \mathrm{m}^{-2} . \mathrm{s}^{-2}\right)$ ou escuro contínuo por 56 dias, quando foi calculada a porcentagem de calos formados.

\section{2..3 Antioxidantes}

Além do controle (MS sem adição de antioxidantes), foram testados os efeitos do carvão ativado ( $2 \mathrm{~g} / \mathrm{L})$, ácido cítrico $(150 \mathrm{mg} / \mathrm{L})$ e ácido ascórbico $(150 \mathrm{mg} /$ L) no meio MS completo e com as vitaminas e o aminoácido nas mesmas concentrações utilizadas para induzir a calogênese, suplementado também com $10 \mathrm{mg} / \mathrm{L}$ de 2,4-D e 2,0 mg/L de 6-BAP. No controle da oxidação, discos de foliólolos jovens foram inoculados com a superfície abaxial voltada para o meio, onde 10 amostras foram mantidas na luz e 10 no escuro constante. $\mathrm{O}$ delineamento experimental utilizado seguiu o esquema fatorial 4x2 (tratamentos x luz/escuro), e os parâmetros analisados foram coloração da superfície adaxial do explante e porcentagem de calos formados. O escurecimento (oxidação) foi calculado em porcentagem, utilizando-se o padrão de classificação apresentado na Figura 1D-F, o que consistiu em níveis de oxidação baixo, médio e alto.

\subsection{Indução de embriões somáticos}

Calos de C. echinata com aproximadamente 30 a 45 dias, previamente cultivados em meio MS com 5 a $20 \mathrm{mg} / \mathrm{L}$ de 2,4-D, foram cultivados por 30 dias em meio MS sem fitorreguladores, para eliminar o efeito residual do 2,4-D. Os calos foram repicados e transferidos para seis tratamentos, sendo T1: meio MS sem fitorreguladores (controle); T2: MS + 2,0 mg/L 2,4-D; T3: MS + 2,0 mg/L 2,4-D + 3,0 mg/L 6-B AP (6benzilaminopurina); T4: MS + 2,0 mg/L 2,4-D + 8,0 mg/ L 6-BAP; T5: MS + 3,0 mg/L 6-BAP; e T6: MS + 8,0 $\mathrm{mg} / \mathrm{L}$ 6-BAP. A cada 30 dias, os calos eram repicados, a fim de renovar o meio de cultura e, assim, evitar a oxidação e depleção excessiva de nutrientes no meio. Após 75 dias de cultivo, os calos foram transferidos para novos meios de cultura, em que a concentração de 6-BAP foi reduzida a $10 \%$ do valor inicial, enquanto a concentração de 2,4-D foi reduzida à $25 \%$ do valor inicial. No caso dos tratamentos em que havia combinação de 2,4-D e 6-BAP, apenas a concentração de 2,4-D foi reduzida em $25 \%$, como se segue: $\mathrm{T} 7: \mathrm{MS}+0,5 \mathrm{mg} /$ L 2,4-D; T8: MS + 0,5 mg/L 2,4-D + 3,0 mg/L 6-BAP; T9: MS + 0,5 mg/L 2,4-D + 8,0 mg/L 6-BAP; T10: MS + 0,3 mg/L 6-BAP; e T11: MS + 0,8 mg/L 6-BAP.
Foram avaliadas as colorações dos calos (translúcida, verde, marrom e marrom-oxidada), presença de estruturas filamentosas, massas pró-embriogênicas (MPEs) e embriões somáticos (Figura 1G-L).

\subsection{Organogênese direta}

Segmentos de ápices caulinares foram isolados e inoculados em meio de cultura MS completo, suplementado com as vitaminas e o aminoácido utilizados na indução da calogênese. A assepsia dos explantes foi realizada em câmara de fluxo laminar com a imersão dos explantes em álcool etílico $70 \%$ por 1 min, seguido de imersão em solução comercial de hipoclorito de sódio com 3-5\% de cloro ativo, durante $20 \mathrm{~min}$, em constante agitação, seguida de três enxagues de água destilada estéril. Os tratamentos consistiram em adicionar ao meio de cultura as concentrações de $0 ; 0,5 ; 1,0 ; 2,0$; 5,0; e 10 mg/L 6-BAP. Antes da adição do ágar, o pH do meio de cultura foi ajustado para 5,8 e autoclavado por $20 \mathrm{~min}$ a $121{ }^{\circ} \mathrm{C}$. Sob estereomicroscópio, foram excisados os segmentos de ápices com aproximadamente $0,5 \mathrm{~cm}$ de comprimento.

Os dados foram submetidos à análise de variância, utilizando-se o software ASSISTAT. Para comparação das médias, foi usado o teste Tukey a $1 \%$ de probabilidade.

Tabela 1 - Porcentagem de calos formados utilizando-se discos de foliólulos juvenil, jovem e maduro de desenvolvimento de C. echinata inoculados em meio MS contendo 0, 5, 10, 20, 50 e $100 \mathrm{mg} / \mathrm{L}$ de 2,4D após 56 dias de cultivo. Letras semelhantes não diferem pelo teste de Tukey $(\mathrm{P}<1 \%)$ onde letras minúsculas comparam dentro de coluna e maiúsculas na linha.

Table 1-Percentage of callus formed on discs from juvenile, young and mature leaves of $C$. echinata inoculated on MS media containing 0, 5, 10,20,50 and 100 $m g / L$ of 2,4-D after 56 days in culture. Similar letter do not differ by Tukey Test $(P<1 \%)$ where lowercase compare within column and capitals in the line.

\begin{tabular}{cccc}
\hline \multicolumn{4}{c}{ Formação de calos $(\%)$} \\
\hline $2,4-\mathrm{D} \mathrm{mg} / \mathrm{L}$ & Juvenil & Jovem & Maduro \\
0 & $0 \mathrm{bA}$ & $0 \mathrm{bA}$ & $0 \mathrm{bA}$ \\
5 & $75 \mathrm{aA}$ & $0 \mathrm{bC}$ & $35 \mathrm{aB}$ \\
10 & $90 \mathrm{aA}$ & $5 \mathrm{bB}$ & $30 \mathrm{abB}$ \\
20 & $85 \mathrm{aA}$ & $10 \mathrm{bB}$ & $35 \mathrm{aB}$ \\
50 & $30 \mathrm{bB}$ & $75 \mathrm{aA}$ & $20 \mathrm{abB}$ \\
100 & $20 \mathrm{bB}$ & $65 \mathrm{aA}$ & $30 \mathrm{abB}$ \\
\hline
\end{tabular}




\section{RESULTADOS}

A indução de calos em C. echinata ocorreu entre 7 e 21 dias após a inoculação, iniciando-se o processo de desdiferenciação na nervura central e na borda dos discos (dados não apresentados). A calogênese só ocorreu na presença de 2,4-D, independentemente das condições de luminosidade (Tabela 1 e Figura 2). As respostas às concentrações de 2,4-D foram associadas à fase de desenvolvimento dos explantes. Melhores respostas ocorreram em foliólolos juvenis nas concentrações mais baixas de 2,4-D ( 5 a $20 \mathrm{mg} / \mathrm{L}$ ) e folíolos jovens nas concentrações mais elevadas (50 e $100 \mathrm{mg} / \mathrm{L}$ ) (Tabela 1).

A utilização de substâncias antioxidantes e a ausência de luz não foram eficientes no controle do processo degenerativo dos calos (Figura 3). O melhor tratamento no controle de oxidação foi o carvão ativado, em que $40 \%$ dos explantes apresentaram oxidação baixa a moderada, porém sem formação de calos. No entanto, foi na presença de ácido ascórbico no escuro que ocorreu maior desenvolvimento de calos, em que $85 \%$ dos explantes geraram calos (Figura 4).

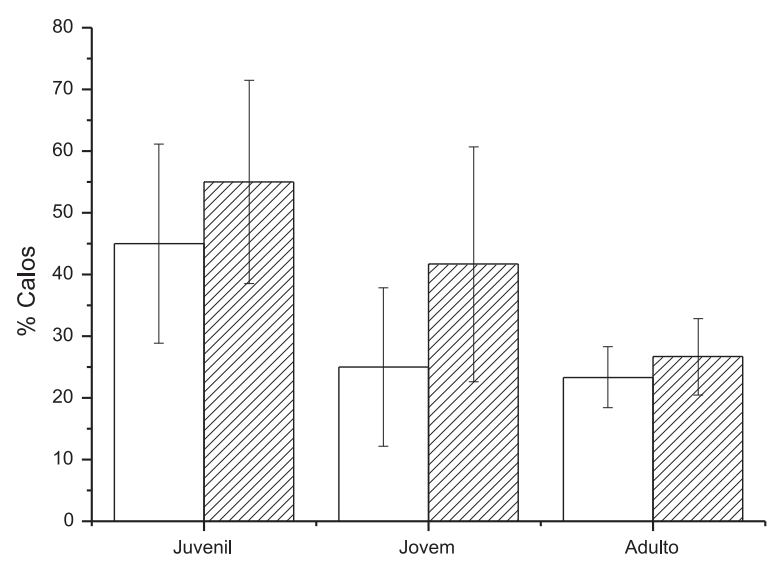

Figura 2 - Porcentagem de calos formados de discos de foliólulos jovens, juvenis e adulto de $C$. echinata cultivados na luz e escuro constante aos 56 dias de cultivo em meio MS com 0, 5, 10, 20, 50 e $100 \mathrm{mg} / \mathrm{L}$ de 2,4-D (n=10). Luz $(\square)$ e escuro $(\square)$. Barras representam o erro padrão.

Figure 2 - Percentage of callus formed from juvenile, young and mature leaves of C. echinata cultured under constant light or dark after 56 days on MS medium with $0,5,10,20,50$ and $100 \mathrm{mg} / \mathrm{L}$ of 2,4-D $(n=10)$. Light $(\square)$ and dark $(\square)$. Bars represent standard error

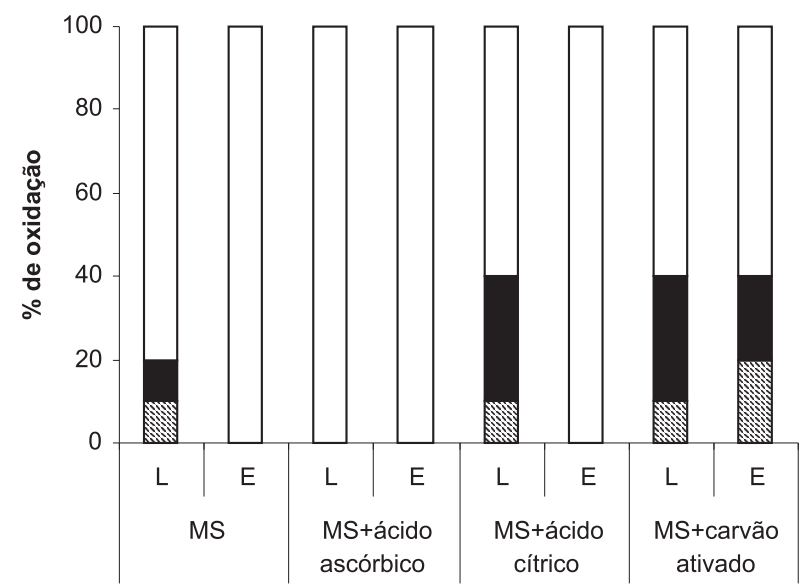

Figura 3 - Porcentagem de oxidação dos discos de foliólulos jovens de C. echinata cultivados na luz e escuro constante e porcentagem de calos formados aos 56 dias de cultivo em meio MS com $10 \mathrm{mg} / \mathrm{L} 2,4-$ $\mathrm{D}$ e $2,0 \mathrm{mg} / \mathrm{L}$ de 6-BAP e suplementado com 150 $\mathrm{mg} / \mathrm{L}$ ácido ascórbico, $150 \mathrm{mg} / \mathrm{L}$ ácido cítrico e $2 \mathrm{~g} / \mathrm{L}$ carvão ativado. $(\mathrm{n}=10)$. Oxidação alta $(\square)$, média $(\square)$ e baixa $(\square)$.

Figure 3 - Percentage of oxidation on young leaves of $C$. echinata cultured under constant light $(L)$ or dark $(E)$ and the percentage of callus formed after 56 days on MS culture media with $10 \mathrm{mg} / \mathrm{L} \mathrm{2,4-}$ $D$ and 2,0 $\mathrm{mg} / \mathrm{L}$ 6-BAP and supplemented with $150 \mathrm{mg} / \mathrm{L}$ of ascorbic acid, $150 \mathrm{mg} / \mathrm{L}$ of citric acid or $2 \mathrm{~g} / \mathrm{L}$ of activated charcoal. $(n=10)$. High $(\square)$, medium $(\square)$ and low $(\square)$ oxidation.

De maneira geral, calos embriogênicos são identificados pela coloração. As porções translúcidobrancas ou amareladas dos calos são consideradas friáveis e com potencial para formarem embriões somáticos (GUERRA et al., 1999; IPEKCI e GOZUKIRMIZI，2005; ARUNYANART e CHAITRAYAGUN, 2005). Independentemente dos tratamentos, a maioria dos calos apresentou coloração heterogênea, podendo identificar áreas de cores translúcidas, marrom-amareladas e verdes (Figura 1 e Tabela 2). Tanto as porções translúcidas quanto as verdes se mostraram friáveis e embriogênicas devido à presença de estruturas globulares próembriogênicas (Figura 1HI), enquanto as porções marrom-amareladas apresentaram aspecto gelatinoso e amorfo, sem a formação de massas próembriogênicas.

Nas duas fases do experimento de indução de embriões somáticos (elevada e baixa concentração de fitorreguladores), maior porcentagem de calos

R. Árvore, Viçosa-MG, v.33, n.6, p.987-996, 2009 


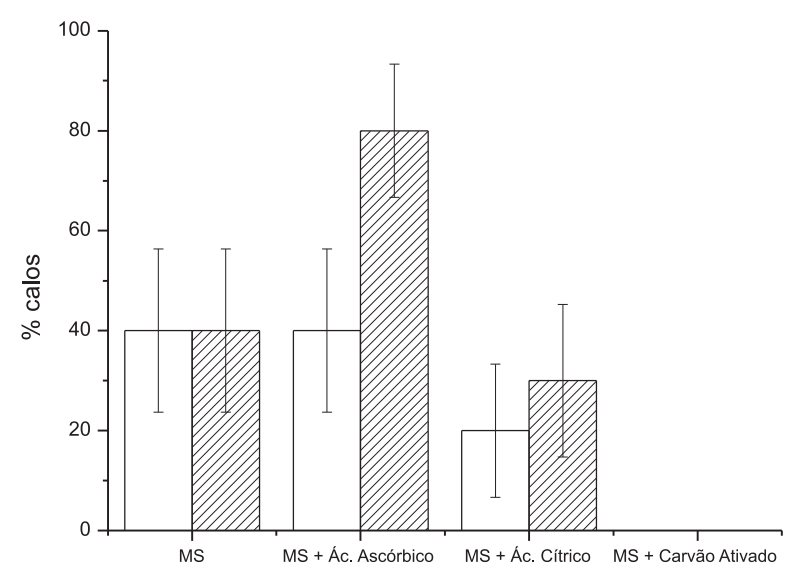

Figura 4 - Porcentagem de calos formados de discos de foliólulos jovens de C. echinata cultivados na luz e escuro constante aos 56 dias de cultivo em meio MS com $10 \mathrm{mg} / \mathrm{L} 2,4-\mathrm{D} \mathrm{e} 2,0 \mathrm{mg} / \mathrm{L}$ de 6-BAP suplementado com $150 \mathrm{mg} / \mathrm{L}$ ácido ascórbico, $150 \mathrm{mg} / \mathrm{L}$ ácido cítrico e $2 \mathrm{~g} / \mathrm{L}$ carvão ativado $(\mathrm{n}=10)$.Luz ( $\square$ ) e escuro $(\square)$. Barras representam o erro padrão.

Figure 4-Percentage of callus formed on discs from young leaves of C. echinata, cultured under constant light or dark after 56 days on MS culture media with $10 \mathrm{mg} / \mathrm{L} 2,4-D$ and 2,O mg/L BAP, supplemented with $150 \mathrm{mg} / \mathrm{L}$ of ascorbic acid, $150 \mathrm{mg} / \mathrm{L}$ of citric acid and $2 \mathrm{~g} / \mathrm{L}$ of activated charcoal $(n=10)$. Light $(\square)$ and dark $(\square)$. Bars represent standard error.

apresentando regiões translúcidas marrons e verdes foi observada em baixas concentrações de 2,4-D. A combinação de 2,4-D e de 6-BAP elevou a porcentagem de calos translúcidos e marrons. Porém, quando cultivados em meio contendo apenas 2,4$\mathrm{D}$, predominaram calos com tonalidades translúcidas e verdes. Os calos de C. equinata cultivados nos diferentes tratamentos formaram massas próembrionárias (MPEs) (Figura 1G-I). Somente em 0,5 $\mathrm{mg} / \mathrm{L} \mathrm{2,4-D}$ apenas $10 \%$ dos calos apresentaram estruturas semelhantes à dos embriões somáticos globulares e codiformes (Figura 1I).

No experimento de organogênese direta, os ápices caulinares, utilizados como explantes, desenvolveram calos em todas as concentrações de 6-BAP. Ocorreu, também, o crescimento de células com colorações esverdeadas, provavelmente originadas da região meristemática, indicando que a organogênese possa ter iniciado (dados não apresentados).

R. Árvore, Viçosa-MG, v.33, n.6, p.987-996, 2009

\section{DISCUSSÃO}

Os resultados da Tabela 1 para indução da calogênese confirmam descrições citadas na literatura ao evidenciarem que a fase de desenvolvimento dos explantes tem grande influência nos processos de desdiferenciação celular e de que órgãos jovens são os mais recomendados como fonte doadora de explantes (THORPE e PATEL, 1984). Segundo Fouda (1996), folhas de ramos juvenis apresentam a epiderme recoberta por uma fina camada de cutícula com alta densidade estomatal e mesófilo espesso em relação às folhas adultas. A maior sensibilidade dos foliólolos jovens às baixas concentrações de 2,4-D pode ser devida à juvenilidade de seus tecidos caracterizados por elevados níveis endógenos de auxinas (TAIZe ZEIGER, 2003).

O desenvolvimento de calo pode ser independente de auxinas e citocininas, dependente de auxinas, dependente de citocininas ou dependente de ambas (JAIND et al., 1995). Em C. echinata, a calogênese foi dependente da concentração da auxina 2,4-D interagindo com a fase de desenvolvimento dos foliólolos. Segundo Grattapaglia e Machado (1990), alta razão auxina/citocininas estimula a proliferação celular, culminando na formação de calos. Essa combinação não foi testada em $C$. echinata devido à não formação de calos em meio MS suplementado apenas com 6-BAP (dados não apresentados).

Considerando os resultados no controle da oxidação (Figura 3), de acordo com Grattapaglia e Machado (1998) o carvão ativado em concentrações de 0,1 a $2 \%$ pode ser benéfico, simulando o escuro onde os explantes se desenvolvem melhor. No entanto, o carvão ativado tem efeito adsorvente, imobilizando parte dos elementos que compõem o meio, inclusive os fitorreguladores. Nesse caso, o aumento da concentração de auxinas tem sido indicado como estratégia para contornar o problema. Aumentando a concentração de 2,4-D em 50 vezes, passando de 10 ìM (sem carvão ativado), para 500 ìM (com 0,3\% de carvão ativado) Teixeira et al. (1993) conseguiram resultados satisfatórios em palmeira-de-óleo (Elacis guineenses). Resultado semelhante foi verificado por Biasi et al. (1994), trabalhando com a propagação do abacateiro in vitro; o ácido ascórbico e o ácido cítrico também não foram eficientes no controle da oxidação de C. echinata. 
A oxidação fenólica é altamente dependente do genótipo, da fase de desenvolvimento da planta e da estação do ano. Em épocas mais favoráveis ao crescimento, a concentração de polifenóis é menor e, consequentemente, a oxidação nos tecidos cultivados in vitro também é menor (PAIVAe PAIVA, 2001). Neste estudo, os explantes foram foliólolos em fase jovem, quando podem apresentar maiores níveis de substâncias oxidantes em relação aos foliólos juvenis (PAIVA e PAIVA, 2001). Além disso, a fase de desenvolvimento da planta-matriz pode ter grande influência no processo de oxidação. A época de coleta dos foliólos de C. echinata ocorreu no verão e, de acordo com a sua fenologia, correspondeu à fase de reprodução sexuada, como confirmada pela visualização de estruturas reprodutivas nas plantasmatriz por ocasião da coleta. Assim, a oxidação fenólica dificultou a prática de micropropagação em C. echinata in vitro.

Com relação à coloração dos calos (Tabela 2), a presença de porções esverdeadas nestes pode ser atribuída à exposição dos calos à luz constante, o que desencadeou a síntese de pigmentos de clorofila nas células de calos translúcidos (CORREDOIRA et al., 2002).
A expressão da embriogênese somática pode ser desencadeada por diferentes fatores, dependendo da espécie e das condições fisiológicas da planta-matriz. No entanto, o procedimento mais comumente utilizado é o da exclusão ou diminuição da concentração de auxina. Segundo Zimmerman (1993), a retirada da auxina do meio de cultura provoca a inativação de uma série de genes e permite que o programa da embriogênese dê continuidade. A aquisição de polaridade em embriões é tida com frequência como o primeiro passo no processo da embriogênese (WARREN e WARREN, 1993), e a divisão assimétrica não resulta diretamente em embrião e, sim, em MPEs, nas quais apenas algumas irão se desenvolver em embriões (NUTI RONCHI e GIORGETTI, 1995). O restante das MPEs deve ter sido eliminado pela morte celular programada (FILONOVA et al., 2000).

Em algumas espécies, a redução da razão auxinas/ citocininas é necessária para a indução da embriogênese somática (GRAY, 2000). Nesse aspecto, Myers (2004) obteve MPEs e o subsequente desenvolvimento de embriões somáticos a partir de sementes imaturas de Delonix regia, uma Fabaceae, em meios de cultura contendo 2,4-D ( 1 a $4 \mathrm{mg} / \mathrm{L})$ combinado com $\operatorname{BAP}(0,1$ a $0,5 \mathrm{mg} / \mathrm{L})$. Mesmo com a proximidade taxonômica entre Delonix e Caesalpinia, o balanço hormonal de auxina

Tabela 2- Porcentagem da coloração dos calos de C. echinata aos 45 dias de cultivo em meio MS suplementado com 2,4D e 6-BAP e 30 dias pós a transferência para meio MS com 2,4-D reduzido à $25 \%$ valor inicial e 6-BAP reduzido à $10 \%$ do valor inicial $(\mathrm{n}=10) . \mathrm{T}=$ translúcido, $\mathrm{V}=$ verde, $\mathrm{M}=$ marrom e $\mathrm{MO}=$ marrom oxidado. Letras semelhantes não diferem pelo teste de Tukey $(\mathrm{P}<1 \%)$ onde letras minúsculas comparam dentro de coluna e maiúsculas na linha.

Table 2 - Color percentage of callus after 45 days of culture on MS media with 2,4-D reduced to $25 \%$ of the initial concentration and BAP reduced to $10 \%$ of the initial concentration $(n=10) . T=$ translucid, $V=$ green, $M=$ brown and $M O$ $=$ oxidized brown. Similar letter do not differ by Tukey Test $(P<1 \%)$ where lowercase compare within column and capitals in the line.

\begin{tabular}{|c|c|c|c|c|c|c|}
\hline \multicolumn{7}{|c|}{ Coloração de calos (\%) } \\
\hline Tratamento & $\mathrm{T} / \mathrm{M} / \mathrm{V}$ & $\mathrm{T} / \mathrm{M}$ & $\mathrm{T} / \mathrm{V}$ & $\mathrm{M} / \mathrm{V}$ & M & $\mathrm{MO}$ \\
\hline \multicolumn{7}{|l|}{45 dias de cultura } \\
\hline$\overline{\text { Controle }}$ & $100 \mathrm{aA}$ & $0 \mathrm{bC}$ & $0 \mathrm{bC}$ & $0 \mathrm{bA}$ & $0 \mathrm{bA}$ & $0 \mathrm{bA}$ \\
\hline $2,0 \mathrm{mg} / \mathrm{L} \mathrm{2,4-D}$ & $50 \mathrm{aB}$ & $0 \mathrm{bC}$ & $40 \mathrm{aA}$ & $10 \mathrm{bA}$ & $0 \mathrm{bA}$ & $0 \mathrm{bA}$ \\
\hline $2,0 \mathrm{mg} / \mathrm{L} 2,4-\mathrm{D}$ e $3,0 \mathrm{mg} / \mathrm{L} \mathrm{BAP}$ & $10 \mathrm{bC}$ & $40 \mathrm{aA}$ & $0 \mathrm{bC}$ & $20 \mathrm{bA}$ & $10 \mathrm{bA}$ & $20 \mathrm{bA}$ \\
\hline $2,0 \mathrm{mg} / \mathrm{L} 2,4-\mathrm{D}$ e $8,0 \mathrm{mg} / \mathrm{L} \mathrm{BAP}$ & $60 \mathrm{aB}$ & $20 \mathrm{bB}$ & $0 \mathrm{cC}$ & $0 \mathrm{cA}$ & $20 \mathrm{bA}$ & $0 \mathrm{cA}$ \\
\hline $3,0 \mathrm{mg} / \mathrm{L} \mathrm{BAP}$ & 70 aAB & $30 \mathrm{bAB}$ & $0 \mathrm{cC}$ & $0 \mathrm{cA}$ & $0 \mathrm{cA}$ & $0 \mathrm{cA}$ \\
\hline $8,0 \mathrm{mg} / \mathrm{L} \mathrm{BAP}$ & $50 \mathrm{aB}$ & $0 \mathrm{bC}$ & $10 \mathrm{bB}$ & $10 \mathrm{bA}$ & $20 \mathrm{bA}$ & $0 \mathrm{bA}$ \\
\hline \multicolumn{7}{|c|}{30 dias após a transferência em nova composição de reguladores } \\
\hline Controle & $100 \mathrm{aA}$ & $0 \mathrm{bB}$ & $0 \mathrm{bB}$ & $0 \mathrm{bA}$ & $0 \mathrm{bB}$ & $0 \mathrm{bB}$ \\
\hline $0,5 \mathrm{mg} / \mathrm{L} \mathrm{2,4- \textrm {D }}$ & $56 \mathrm{aB}$ & $08 \mathrm{cB}$ & $32 \mathrm{bA}$ & $10 \mathrm{cA}$ & $0 \mathrm{cB}$ & $0 \mathrm{cB}$ \\
\hline $0,5 \mathrm{mg} / \mathrm{L} 2,4-\mathrm{D}$ e $3,0 \mathrm{mg} / \mathrm{L}$ BAP & $0 \mathrm{cD}$ & 38 aA & $13 \mathrm{bB}$ & $12 \mathrm{bA}$ & $12 \mathrm{bB}$ & 25 aA \\
\hline $0,5 \mathrm{mg} / \mathrm{L} 2,4-\mathrm{D}$ e $8,0 \mathrm{mg} / \mathrm{L} \mathrm{BAP}$ & $33 \mathrm{aC}$ & 33 aA & $11 \mathrm{~b} \mathrm{~B}$ & $11 \mathrm{bA}$ & $12 \mathrm{bB}$ & $0 \mathrm{bB}$ \\
\hline $0,3 \mathrm{mg} / \mathrm{L}$ BAP & $56 \mathrm{aB}$ & $44 \mathrm{aA}$ & $0 \mathrm{bB}$ & $0 \mathrm{bA}$ & $0 \mathrm{bB}$ & $0 \mathrm{bB}$ \\
\hline $0,8 \mathrm{mg} / L \mathrm{BAP}$ & $67 a B$ & $O c B$ & $O c B$ & $O c A$ & $33 b A$ & $O c B$ \\
\hline
\end{tabular}


e citocinina não gerou embriões somáticos em C. echinata. Tais informações sugerem que as concentrações ou, ainda, a razão entre as concentrações de 2,4-D e 6-BAP testadas neste trabalho não foram as ideais para a expressão da embriogênese somática. Há casos em que a associação de 2,4-D e 6-BAP não é eficiente na indução e expressão da embriogênese somática. Ipekci e Gozukirmizi (2005) conseguiram melhor produção de embriões somáticos a partir de folhas de Paulownia elongata (Schrophulariacea) em meio MS contendo 0,1 mg/L de TDZ (1-fenil-3-(1,2,3tiadiazol-5-il)ureia]) e 1,0 mg/L de cinetina. Outros estudos, como os de Junaid et al. (2006), têm demonstrado que, depois de adquirir competência embriogênica, a substituição do 2,4-D por outros fitorreguladores como o ANA pode estimular a formação de embriões somáticos.

Em todos os tratamentos testados com C. echinata ocorreu a formação de calos com estruturas filamentosas na sua superfície (Figura 1G). Segundo Barrueto (1992) e Chaudhury e Qu (2000), essas estruturas são elementos diferenciados, como fibras e traqueídeos, indicando que tais porções dos calos não conseguiram se desdiferenciar, não sendo, por isso, embriogênicas.

Embora não se tenha definido a formulação para a expressão de embriões somáticos, este trabalho revelou que essa espécie necessita de elevadas concentrações de auxina, como o 2,4-D, para indução da calogênese. Outro aspecto relevante é o fato de que a transferência para meio reduzido ou sem fitorreguladores induz algumas formações incipientes de MPEs. Esse mecanismo de diferenciação celular pode ser controlado, entre outras maneiras, utilizando-se outros meios de cultura ou diminuindo as concentrações de nutrientes (ANDERSON, 1984). Além do uso de fitorreguladores, a osmolaridade associada ao ácido abscísico pode ser uma alternativa para a expressão da embriogênese somática (GUERRA et al., 1999).

\section{CONCLUSÕES}

Os resultados deste estudo evidenciam que:

- Folíolos juvenis de C. echinata em meio MS contendo 5 e $20 \mathrm{mg} / \mathrm{L}$ de 2,4-D e folíolos jovens em 50 e $100 \mathrm{mg} / \mathrm{L}$ de 2,4-D formam calos.

- O carvão ativado controla a oxidação e inibe a calogênese.

- Meio livre de fitorreguladores estimula algumas formações de massas pró-embrionárias (MPEs).
Contudo, ainda não foi possível a formação de embriões somáticos; apenas algumas estruturas semelhantes à desses embriões nas fases globular e codiforme foram identificadas em $0,5 \mathrm{mg} / \mathrm{L} \mathrm{2,4-D.}$

\section{AGRADECIMENTOS}

À Fundação Biodiversitas, à Fundação de Apoio à Pesquisa do Espírito Santo - FAPES (Processo 39044823/2007) e ao Fundo de Apoio Científico e Tecnológico da Prefeitura Municipal de Vitória FACITEC (Processo 38/2007), pelo apoio financeiro.

\section{REFERÊNCIAS}

AGUIAR, F. F. A. et al. Maturação de frutos de Caesalpinia echinata Lam., Pau-Brasil.

Revista Árvore, v.31, n.1, p.1-6, 2007.

AGUIAR, F. F. A. et al. Germinação de sementes e formação de mudas de Caesalpinia echinata Lam. (Pau - Brasil): efeito de sombreamento. Revista Árvore, v.29, n.6, p.871-875, 2005.

ANDERSON, W. C. A revised culture tissue medium for shoot multiplication of rhododendron. Journal of American Society Horticulturae of Science, v.109, n.3, p.343-347, 1984.

ARUNYANART, S.; CHAITRAYAGUN, M. Induction of somatic embryogenesis in lotus (Nelumbo nucifera Geartn.). Scientia Horticulturae, v.105, n.3, p.411-420, 2005.

BARBEDO, C. J.; BILIA, D. A. C.; FIGUEIREDO-RIBEIRO, R. C. L. Tolerância à dessecação e armazenamento de sementes de Caesalpinia echinata Lam. (pau-brasil), espécie da Mata Atlântica. Revista Brasileira de Botânica, v.25, n.4, p.431439, 2002.

BARRUETO CID, L. P. A cultura de células vegetais em meio líquido. ABCTP

Notícias, v.18, n.1, p.2-7, 1992.

BIASI, L. A.; KOLLER, O. C.; KAMPF, A. N. Micropropagação do abacateiro 'Ouro Verde' a partir de segmentos nodais. Pesquisa Agropecuária Brasileira, v.29, n.7, p.1051-1058, 1994. 
BRASIL. Portaria ${ }^{\circ}$ 006-N, de 15 de Janeiro de 1992. Dispõe sobre a Lista Oficial de Espécies da Flora Brasileira Ameaçadas de Extinção.

Diário Oficial da República

Federativa do Brasil, Brasília, 23 jan. Seção 1, v.130, n.16, 1992.

CARVALHO, J. F. R. P.; CARVALHO, C. R.; OTONI, W. C. Regeneração in vitro de Urucum (Bixa Orellana L.) a partir de diferentes tipos de explantes. Revista Árvore, v.29, n.6, p.887-895, 2005.

CARVALHO, P. E. R. Espécies florestais brasileiras - recomendações silviculturais, potencialidades e uso da madeira. Brasília: Embrapa-CNPF/SPI, 1994. p.113-117.

CHAUDHURY, A.; QU, R. Somatic embryogenesis and plant regeneration of turftype bermudagrass: Effect of 6-benzyladenine in callus induction medium. Plant Cell, Tissue and Organ Culture, v.60, n.2, p.113-120, 2000.

CORREDOIRA, E.; VIEITEZ, M. A.; BALLESTER, A. Somatic embryogenesis in Elm. Annals of Botany, v. 89, n.5, p.637-644, 2002.

FILONOVA, L. H. et al. Two waves of programmed cell death occur during formation and development of somatic embryos in the gymnosperm, Norway spruce. Journal of Cell Science, v.113, n.24, p.4399-4411, 2000.

FOUDA, R. A. Anatomical characteristics of juvenile and adult shoots associated with rooting ability of Cupressocyparis leylandii cuttings. Horticultural Science, v. 28, n.1, p.107-111, 1996.

GRATTAPAGLIA, D.; MACHADO, M. A. Micropropagação. In: TORRES, A. C.; CALDAS, L. S.; BUSO, J. A. (Eds.). Cultura de tecidos e transformação genética de plantas. Brasília: Embrapa/CBAB, 1998. v.1. p.183-260.

GRATTAPAGLIA, D.; MACHADO, M. A. Micropropagação. In: TORRES, A. C.; CALDAS, L. S. (Eds.). Técnicas e aplicações da cultura de tecidos de plantas. Brasília: ABCTP/Embrapa-CNPH, 1990. p.99-169.
GRAY, D. J. Nonzygotic embryogenesis. In: TRIGIANO, R. N.; GRAY, D. J. (Eds.). Plant tissue culture concepts and laboratory exercises. Boca Raton: CRC Press, 2000. p.175-189.

GUERRA, M. P.; TORRES, A. C.; TEIXEIRA, J. B. Embriogênese somática e sementes sintéticas. In: TORRES, A. C.; CALDAS, L. S.; BUSO, J. A. (Eds.). Cultura de tecidos e transformação genética de plantas. Brasília: Embrapa/CBAB, 1999. v.2. p.537-548.

IPEKCI, Z.; GOZUKIRMIZI, N. Indirect somatic embryogenesis and plant regeneration from leaf and internode explants of Paulownia elongata. Plant Cell, Tissue and Organ Culture, v.79, n.3, p.341-345, 2005.

JAIN, S. M.; GUPTA, P. K.; NEWMAN, R. J. Somatic embryogenesis in woody plants. Dordrecht: Kluwer Acadamic Publishers, 1995. v.2.

JUNAID, A. et al. Somatic embryo proliferation, maturation and germination in Catharanthus roseus. Plant Cell, Tissue and Organ Culture, v.84, n.3, p.325-332, 2006.

LIMA, H. C. Aspectos botânicos do Pau-Brasil. In: CUNHA, M.V.; LIMA, H. C. (Eds.). Viagem à terra do Pau-Brasil. Rio de Janeiro: Agência Brasileira de Cultura, 1992. p.23-38.

MODGIL, M.; SHARMA, D. R.; BHARDWAJ, S. V. Micropropagation of apple cv. Tydeman's Early Worcester. Scientia Horticulturae, v.81, n.2, p.179-188, 1999.

MURASHIGE, T.; SKOOG, F. A. A revised medium for rapid growth and bioassays with tabaco tissue cultures. Physiologia Plantarum, v.15, n.3, p.473-497, 1962.

MYERS, A. Somatic embryogenesis induction in Delonix regia (Boger.) (Royal Poinciana). Journal of Undergraduate Research, v.5, n 6, 2004.

NEWMAN, P.O.; KRISHNARAJ, S.; SAXENA, P.K. Regeneration of tomato (Lycopersicon esculentum), somatic embryogenesis and shoot organogenesis from hypocotyl segments induced with Benzylaminopurine. International Journal Plant Science, v.157, p.554-560, 1996.

R. Árvore, Viçosa-MG, v.33, n.6, p.987-996, 2009 
NUTI RONCHI, V.; GIORGETTI, L. The cell's commitment to somatic embryogenesis. In: BAJAJ, Y.P.S. (Ed.) Somatic embryogenesis and synthetic seed $I$. Biotechnology in agriculture and forestry. Berlin, SpringerVerlag, 1995. v.30. p.3-19.

PAIVA, R.; PAIVA, P. D. O. Cultura de tecidos - Textos acadêmicos. Lavras: UFLA/FAEPE, 2001. 97p.

PREECE, F. E.; COMPTON, M. E. I. Problems with explant exudation in micropropagation. In: BAJAJ, Y. P. S. Biotechnology in agriculture and forestry: High-Tech and micropropagation I. Berlin: Springer Verlag, 1991. p.168-189.

TAIZ, L., ZEIGER, E. Auxina: o hormônio de crescimento. In: Fisiologia vegetal. 3.ed. Porto Alegre: Artmed, 2003. 719p.
TEIXEIRA, J. B.; SÖNDAHL, M. R.; KIRBY, E. G. Somatic embryogenesis from immature zygotic embryos of oil palm. Plant Cell Tissue and Organ Culture, v.34, n.5, p.247-250 1993.

THORPE, T. A.; PATEL, K. R. Clonal propagation: adventitious buds. In: VASIL, I. (Ed.) Cell culture and somatic cell genetics of plants: laboratory procedures and their applications. Orlando: Academic Press, 1984. v.1. p.49-60.

WARREN WILSON, J.; WARREN WILSON, P. M. Mechanism of auxin regulation of structural and physiological polarity in plants, tissues, cells and embryos. Australian Journal of Plant Physiology, v.20, n.5, p.555-571, 1993.

ZIMMERMAN, J. L. Somatic embryogenesis: a model for early development in higher plants. Plant Cell, v.5, n.10, p.1411-1423, 1993. 